\title{
Education does not equally influence all the Mini Mental State Examination subscales and items: inferences from a Brazilian community sample
}

\section{A educação não influencia igualmente todas subescalas e itens do Mini-Exame do Estado Mental: inferências de uma amostra comunitária brasileira}

\author{
Jerson Laks, ${ }^{1}$ Evandro Silva Freire Coutinho, ${ }^{2}$ Washington Junger, ${ }^{3}$ Heitor Silveira, ${ }^{1}$ Raphael Mouta, ${ }^{1}$ Elienai Maria \\ Rubim Baptista, ${ }^{4}$ Ana Lucia Barros Contino, ${ }^{4}$ Maria Lage Barca, ${ }^{1,5}$ Geir Selbaek, ${ }^{6}$ Knut Engedal, ${ }^{5}$ Eliasz Engelhardt ${ }^{1}$

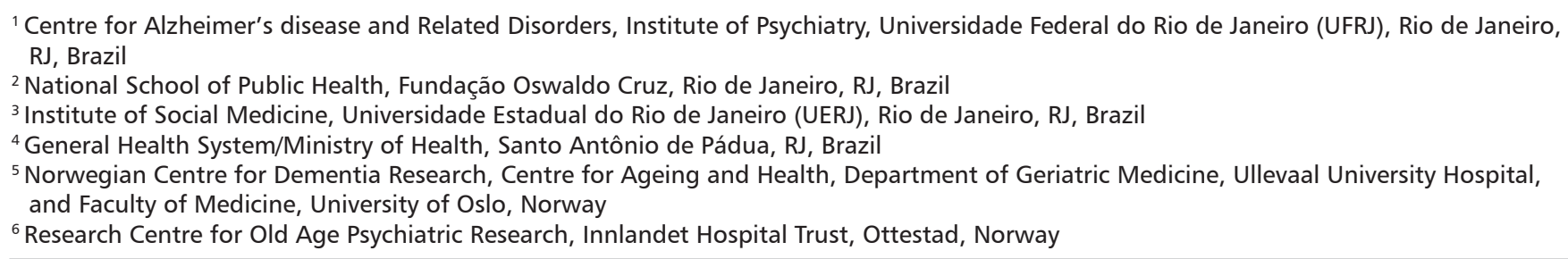

\begin{abstract}
Objective: Mini-Mental State Examination cutoffs have been presented for schooling levels to screen cognitive impairment. However, items may behave differently with regards to education. The objective of this study was to examine the impact of education on MMSE subscales and items. Method: Community-dwelling participants aged 65 years or more $(\mathrm{n}=990$, females $=637$, age $=74.1$ years, range 65-108) were stratified as illiterate $(\mathrm{n}=373), 1-8(\mathrm{n}=540), 9-12(\mathrm{n}=63)$, and more than 12 years of schooling $(n=14)$ and were screened with MMSE and Pfeffer Functional Activities Questionnaire. To make the Mini-Mental State Examination items comparable, each item was transformed into $\mathrm{z}$ scores. Multiple linear regression was used to estimate the effect of schooling on MMSE subscales and items controlling for age, sex, and activities of daily life. Results: Temporal and space orientation, attention/calculation, repetition, reading, writing, and drawing scores improved as education increased, but not memory registration, three step command, and naming. Reading and writing displayed the largest coefficients, whereas education exerted no influence on naming and three step command tasks. Conclusion: Education does not exert an important effect on naming, three step command, memory registration, and delayed recall. As memory is a key factor for diagnosing dementia, these items could be considered despite education.
\end{abstract}

Descriptors: Aged; Dementia; Cognition; Educational status; Mental health

\section{Resumo}

Objetivo: Vários pontos de corte foram propostos para o Mini Exame do Estado Mental para rastrear cognição. Entretanto, os itens podem se comportar diferentemente dependendo da educação. O objetivo deste estudo foi examinar o impacto da educação nas subescalas e itens do Mini Exame do Estado Mental. Método: Participantes com idade de 65 anos ou mais e residentes na comunidade $(n=990$, feminino $=637$, idade $=$ 74,1 anos, 65-108) foram estratificados como analfabetos ( $n=373), 1-8$ $(n=540), 9-12(n=63)$, e mais de 12 anos de escolaridade $(n=14) e$ foram rastreados com Mini Exame do Estado Mental e com Questionário de Atividades Funcionais de Pfeffer. Para tornar os itens do Mini Exame do Estado Mental comparáveis, cada item foi transformado em escore z. Regressão linear múltipla foi usada para estimar o efeito da escolaridade nos subitens do Mini Exame do Estado Mental controlando para idade, sexo e atividades de vida diária. Resultados: Orientação temporal e espacial, atenção/cálculo, repetição, leitura, escrita e desenho melhoraram à medida que a escolaridade aumentava, mas não registro, comando em três etapas e nomeação. Leitura e escrita tiveram os maiores coeficientes, enquanto a eåducação não influenciou na nomeação ou comando em três etapas. Conclusão: Educação não exerce efeito importante em nomeação, comando em três etapas, registro de memória e memória tardia. Sendo memória fator-chave para diagnosticar demência, esses itens podem ser considerados apesar da educação.

Descritores: Idosos; Demência; Cognição; Escolaridade; Saúde mental 


\section{Introduction}

The Mini-Mental State Examination (MMSE) ${ }^{1}$ is viewed as a mandatory test to screen for cognitive impairment and dementia in the various clinical and community settings. Despite its known qualities as a quick and good instrument to assess the overall cognitive state, there is still an ongoing debate on the several shortcomings of this test regarding its appropriateness to recognize dementia with good sensitivity and specificity, either in low or in highly educated subjects. ${ }^{2-3}$ Numerous studies have provided different cutoff scores for cognitive impairment according to age and education both in developed and in developing countries. ${ }^{4-6}$ In Brazil, most studies have examined the psychometric properties of the MMSE only in clinical settings, ${ }^{7-9}$ providing cutoff points ranging from 12 to 19 for illiterate elderly. However, the instrument may behave differently in community samples of older adults. ${ }^{2,10}$ Normative data with the percentile distribution may be more suitable to prospectively examine cognitive impairment and decline, considering those at the $5^{\text {th }}$ or $10^{\text {th }}$ percentile as impaired or at greater risk of having dementia. ${ }^{11,12}$ A recent study ${ }^{13}$ with a large community based sample showed that it is inadequate to use means and standard deviations to set cutoff points for the MMSE given that the distribution of the scores is not normal, but is rather skewed to the right, even when the participants were stratified for age and schooling level. This is in line with previous observations that the MMSE scores are not normally distributed and, therefore, these data would need statistical methods other than multiple linear regression models and discriminate analysis to be properly understood. ${ }^{14}$

A qualitative approach to the MMSE items may provide additional information on subtle changes which can be further examined with other neuropsychological tests designed to cover a broader range of cognitive abilities. ${ }^{15-17}$ Patients with mild cognitive impairment, for instance, tend to score above the established cutoff points of the MMSE. ${ }^{15,18}$ There is a need to inform clinicians about the size of the impact of sociodemographic variables on the MMSE scores, rather than just setting cutoff scores for education. ${ }^{10}$ Several studies have identified and confirmed five domains within the MMSE, 19,20 namely, orientation, registration, attention and calculation, recall and language. Albeit it has already been well established that education may exert a major effect on the total score of the MMSE, ${ }^{2-4,10}$ Jones and Gallo ${ }^{20}$ and other authors ${ }^{19}$ have found that the MMSE is construct valid to all the educational levels, although the internal consistency reliability was higher among those with less education. ${ }^{21}$ These authors hypothesized that the MMSE would relate equivalently to external variables such as sex, functionality, occupational status, and physical health, and would also display equivalent internal characteristics across education but the results did not confirm their assumptions. ${ }^{21}$ These findings were further extended to study samples comprising illiterates, as in publications which assessed MMSE in developing countries. ${ }^{12,19}$ The purpose of the present study is to examine the impact of education on each item of the MMSE in such a population in Brazil. We hypothesized that not all of the MMSE items would have the same impact from educational level to the final score. In this case, at least some of the items could hold a good validity to screen for cognitive impairment regardless of the subject's educational background.

\section{Method}

\section{Participants and setting}

Participants with more than 65 years of age from a project to evaluate the prevalence of dementia in Santo Antonio de Pádua, Brazil were screened with the MMSE ${ }^{1}$ and the Pfeffer Functional Activities Questionnaire (PFAQ). ${ }^{22}$ Santo Antonio de Pádua is located in the state of Rio de Janeiro, southeast of Brazil, and has approximately 4,614 individuals with more than 60 years of age (11.92\% of the total population) from a total of 38,692 inhabitants. ${ }^{23}$ The elderly living in nine sections of the city were consecutively included from May/2000 in an observational cross-sectional study. Seven hundred and forty six subjects were evaluated in the community. The other subjects ( $\mathrm{n}=529$ ) were evaluated at a public neurology outpatient unit. The available data was joined into one group because both groups share the same demographic, social, educational, and age characteristics. ${ }^{24}$ The original database included 1,275 subjects. For the present study, subjects with more than 65 years of age were selected from the database complying with the cutoff age to define old age. This would make comparisons with other studies more accurate. Those with less than 65 years of age $(n=230)$ or with hearing and visual impairments and/or clinical unstable disorders ( $n=10)$, which would make the examination impossible, were excluded from this study. These impairments and disorders were investigated by using a structured questionnaire designed by the authors. Also, four subjects were not able to ascertain their age and 41 other subjects were excluded because of incomplete recorded data.

The subjects' age, gender and educational level were recorded following a direct question regarding these data. The level of activity of daily living was assessed (ADL) by the PFAQ, ${ }^{22}$ providing operational descriptions of various functional levels. Performance in all activities is assessed by 10 questions with the score ranging from 0 to 3 , according to increasing severity. The maximum possible score is 30 . Functional capacity level varies from 1 (normal) to 7 (severely incapacitated). Subjects scoring higher than 5 are defined as having functional impairment.

The MMSE is a brief screening test for cognitive capabilities. It evaluates orientation (spatial and time), attention, concentration, memory, calculation, language, and praxis. The score ranges from 0 to 30 , and the higher the score, the better is the performance. The MMSE structure includes 16 binomially scored items (time orientation, space orientation, naming, repetition, reading, writing, and drawing) of which time and space orientation may be contracted so as to be scored on an ordinal scale, ranging each one from $0-5$. The other items are scored ordinally, namely memory registration, attention/ calculation, and delayed memory. ${ }^{14}$ In this study, we used a Brazilian version of the MMSE and only scored the serial sevens as the item for attention/concentration and calculation. ${ }^{25}$ 


\section{Statistics}

The R software ${ }^{26}$ was used for data analysis. Relative frequencies were calculated for categorical variables. Statistical significance of the difference between the categories was evaluated by chi-squared test. Means and standard deviations were estimated for continuous variables and scores of three subscales (time orientation, space orientation, and naming) and eight single items of the MMSE. Scores for the three subscales and the eight items were also calculated according to education categories. The statistical significance of the differences among the various education categories was calculated using the Kruskal-Wallis test. In order to make the MMSE items comparable, each item was transformed into $z$ scores, i.e., the mean was subtracted from each value of a determined variable and the result was divided by one standard deviation. Multiple linear regression was used to estimate the effect of schooling on each item of the MMSE controlling for age, sex, and activities of daily life (ADL). The regression coefficient estimate represents the variation in standard deviations in the $z$ score for each level of schooling as compared to the baseline level, i.e., illiteracy. Marginal effects can be easily derived by subtracting the value of the previous level from the coefficient of a given level of schooling. In this study, a lower statistical significance was expected for the highest level of schooling because there were only a few subjects in this category who were included in the study population. P-values $\leq 0.05$ were considered statistically significant. Those values between 0.06 and 0.10 were considered of borderline significance.

\section{Ethics}

The study was approved by the Ethics Committee of the Institute of Psychiatry of the Universidade Federal do Rio de Janeiro (no.1127/2005), and the participants signed the informed consents.

\section{Results}

Nine hundred ninety subjects were interviewed and 637 (64\%) were women. The mean age of the population was 74.1 years, ranging from 65 to 108 . Women were older than men, with a borderline statistically significant difference in years (74.4 vs. 73.5, $\mathrm{p}=0.06$ ). The sample was stratified for schooling (years of formal
Table 1 - Demographic Profile of the sample and MMSE subscales and item scores $(n=990)$

\begin{tabular}{|c|c|c|}
\hline Variable & Mean or $n$ & $\mathrm{SD}^{\star}$ or $\%$ \\
\hline \multicolumn{3}{|l|}{ Gender } \\
\hline Male & 353 & $35.6 \%$ \\
\hline Female & 637 & $64.4 \%$ \\
\hline \multicolumn{3}{|l|}{ Education (years) } \\
\hline Illiterate & 373 & $37.7 \%$ \\
\hline $1-8$ & 540 & $54.5 \%$ \\
\hline $9-12$ & 63 & $6.4 \%$ \\
\hline$>12$ & 14 & $1.4 \%$ \\
\hline Age & 74.1 & $6.8 \%$ \\
\hline \multicolumn{3}{|l|}{$\begin{array}{l}\text { MMSE subscales and items } \\
\text { scores }\end{array}$} \\
\hline Time orientation $(0-5)^{\star \star}$ & 3.2 & 1.5 \\
\hline Space orientation (0-5) & 4.0 & 1.2 \\
\hline Memory registration (0-3) & 2.8 & 0.5 \\
\hline Attention/calculation (0-5) & 2.0 & 2.0 \\
\hline Delayed Memory (0-3) & 2.0 & 1.0 \\
\hline Naming $(0-2)$ & 2.0 & 0.2 \\
\hline \multicolumn{3}{|l|}{ Repetition (0-1) } \\
\hline 0 & & $50 \%$ \\
\hline 1 & & $50 \%$ \\
\hline Three step command (0-3) & 2.7 & 0.7 \\
\hline \multicolumn{3}{|l|}{ Reading $(0-1)$} \\
\hline 0 & & $50 \%$ \\
\hline 1 & & $50 \%$ \\
\hline \multicolumn{3}{|l|}{ Writing (0-1) } \\
\hline 0 & & $64.4 \%$ \\
\hline 1 & & $35.6 \%$ \\
\hline \multicolumn{3}{|l|}{ Drawing $(0-1)$} \\
\hline 0 & & $60 \%$ \\
\hline 1 & & $40 \%$ \\
\hline ADL & 5.1 & 8.3 \\
\hline
\end{tabular}

* Standard deviation of the mean

${ }^{* *}$ Range of possible scores

education) as follows: illiterate $(\mathrm{n}=373), 1-8(\mathrm{n}=540), 9-12(\mathrm{n}=$ $63)$, and more than 12 years of schooling $(n=14)$. More women were illiterate than men ( $41 \%$ vs. $32 \%, p=0.004)$.

The profile of the sample and the MMSE scores and respective standard deviations (SD) are depicted in Table 1.

Table 2 - MMSE subscales and items scores according to education, not controlled by sex, and activities of daily living. Data expressed as Mean (standard deviation) $(n=990)$

\begin{tabular}{lccccc}
\hline \multicolumn{1}{c}{$\begin{array}{c}\text { MMSE subscales and items } \\
\text { scores }\end{array}$} & $\begin{array}{c}\text { Illiterate } \\
\mathbf{n = 3 7 3}\end{array}$ & $\begin{array}{c}\mathbf{1 - 8} \text { years } \\
\mathbf{n = 5 4 0}\end{array}$ & $\begin{array}{c}\mathbf{9 - 1 2} \\
\mathbf{n = 6 3}\end{array}$ & $\begin{array}{c}\text { > 12 } \\
\mathbf{n}=\mathbf{1 4}\end{array}$ & $\begin{array}{c}\text { Kruskall Wallis } \\
\mathbf{p} \text {-value }\end{array}$ \\
\hline Time orientation & $2.57(1.39)$ & $3.46(1.37)$ & $4.36(1.25)$ & $3.93(1.59)$ & 0.001 \\
Space orientation & $3.31(1.33)$ & $4.29(1.04)$ & $4.84(0.74)$ & $4.93(0.27)$ & 0.001 \\
Memory registration & $2.76(0.62)$ & $2.90(0.36)$ & $2.97(0.18)$ & $3.00(0.00)$ & 0.001 \\
Attention/calculation & $0.74(1.32)$ & $2.46(1.95)$ & $4.40(1.40)$ & $4.28(1.49)$ & 0.001 \\
Delayed memory & $2.06(1.03)$ & $1.90(1.02)$ & $1.81(0.80)$ & $2.00(0.88)$ & 0.01 \\
Naming & $1.94(0.29)$ & $1.97(0.22)$ & $1.97(1.77)$ & $1.93(0.27)$ & 0.36 \\
Repetition & $0.42(0.49)$ & $0.53(0.49)$ & $0.74(0.44)$ & $0.71(0.47)$ & 0.001 \\
Three step command & $2.61(0.71)$ & $2.68(0.66)$ & $2.79(0.44)$ & $2.86(0.36)$ & 0.13 \\
Reading & $0.96(0.29)$ & $0.63(0.48)$ & $0.90(90.29)$ & $0.93(0.27)$ & 0.001 \\
Writing & $0.52(0.22)$ & $0.47(0.49)$ & $0.92(0.27)$ & $1.00(0.00)$ & 0.001 \\
Drawing & $0.12(0.32)$ & $0.42(0.49)$ & $0.80(0.39)$ & $0.75(0.45)$ & 0.001 \\
\hline
\end{tabular}


Table 3 - Standardized coefficients of educational categories for different items of the Mini Mental Exam, adjusted for gender, age, and functional status $(n=990)$

\begin{tabular}{|c|c|c|c|c|}
\hline Subscale & Education & Coefficient $^{\star}$ & $S E^{\star \star}$ & p-value \\
\hline \multirow[t]{4}{*}{ Time orientation } & Illiterate: $n=373$ & Reference & & \\
\hline & $1-8: n=540$ & 0.46 & 0.05 & $<0.0001$ \\
\hline & $9-12: n=63$ & 0.93 & 0.10 & $<0.0001$ \\
\hline & $>12: n=14$ & 0.73 & 0.20 & 0.0002 \\
\hline \multirow[t]{4}{*}{ Space orientation } & Illiterate: $n=373$ & Reference & & \\
\hline & $1-8: n=540$ & 0.65 & 0.05 & $<0.0001$ \\
\hline & $9-12: n=63$ & 1.00 & 0.10 & $<0.0001$ \\
\hline & $>12: n=14$ & 1.11 & 0.21 & $<0.0001$ \\
\hline \multirow[t]{4}{*}{ Memory registration } & Illiterate: $n=373$ & Reference & & \\
\hline & 1-8: $n=540$ & 0.23 & 0.06 & 0.0004 \\
\hline & $9-12: n=63$ & 0.26 & 0.13 & 0.049 \\
\hline & $>12: n=14$ & 0.36 & 0.26 & 0.155 \\
\hline \multirow[t]{4}{*}{ Attention/calculation } & Illiterate: $n=373$ & Reference & & \\
\hline & $1-8: n=540$ & 0.73 & 0.05 & $<0.0001$ \\
\hline & $9-12: n=63$ & 1.64 & 0.11 & $<0.0001$ \\
\hline & $>12: n=14$ & 1.57 & 0.21 & $<0.0001$ \\
\hline \multirow[t]{4}{*}{ Delayed memory } & Illiterate: $n=373$ & Reference & & \\
\hline & 1-8: $n=540$ & -0.23 & 0.06 & 0.0002 \\
\hline & $9-12: n=63$ & -0.44 & 0.13 & 0.0005 \\
\hline & $>12: n=14$ & -0.18 & 0.25 & 0.47 \\
\hline \multirow[t]{4}{*}{ Naming } & Illiterate: $n=373$ & Reference & & \\
\hline & 1-8: $n=540$ & 0.06 & 0.07 & 0.39 \\
\hline & $9-12: n=63$ & -0.02 & 0.14 & 0.90 \\
\hline & $>12: n=14$ & -0.14 & 0.27 & 0.59 \\
\hline \multirow[t]{4}{*}{ Repetition } & Illiterate: $n=373$ & Reference & & \\
\hline & $1-8: n=540$ & 0.18 & 0.07 & 0.006 \\
\hline & $9-12: n=63$ & 0.51 & 0.14 & 0.0002 \\
\hline & $>12: n=14$ & 0.50 & 0.26 & 0.06 \\
\hline \multirow[t]{4}{*}{ Three step command } & Illiterate: $n=373$ & Reference & & 0.70 \\
\hline & 1-8: $n=540$ & 0.02 & 0.06 & 0.52 \\
\hline & $9-12: n=63$ & 0.08 & 0.13 & 0.32 \\
\hline & $>12: n=14$ & 0.25 & 0.25 & \\
\hline \multirow[t]{4}{*}{ Reading } & Illiterate: $n=373$ & Reference & & \\
\hline & $1-8: n=540$ & 1.01 & 0.05 & $<0.0001$ \\
\hline & $9-12: n=63$ & 1.45 & 0.11 & $<0.0001$ \\
\hline & $>12: n=14$ & 1.56 & 0.21 & $<0.0001$ \\
\hline \multirow[t]{4}{*}{ Writing } & Illiterate: $n=373$ & Reference & & \\
\hline & 1-8: $n=540$ & 1.71 & 0.06 & $<0.0001$ \\
\hline & $9-12: n=63$ & 1.71 & 0.11 & $<0.0001$ \\
\hline & $>12: n=14$ & 1.94 & 0.22 & $<0.0001$ \\
\hline \multirow[t]{4}{*}{ Drawing } & Illiterate: $n=373$ & Reference & & \\
\hline & 1-8: $n=540$ & 0.59 & 0.06 & $<0.0001$ \\
\hline & $9-12: n=63$ & 1.33 & 0.12 & $<0.0001$ \\
\hline & $>12: n=14$ & 1.31 & 0.26 & $<0.0001$ \\
\hline
\end{tabular}

${ }^{*}$ Adjusted for age, sex, and Activities of Daily Living; ${ }^{* *}$ SE $=$ Standard Error.

The mean and respective standard deviations (SD) scores of MMSE subscales and items according to education are shown in Table 2. There is a marked significant difference in scores according to duration of education when these data are not controlled by age, sex, and ADL, except for the delayed memory, the naming, and the three step command tasks.
Table 3 shows the influence of education on the three subscales time orientation, space orientation and naming and the eight single items of the MMSE, controlled for age, sex, and ADL. As mentioned before, the variable was standardized in order to allow the comparison of the effects of education on each item, taking into account that the ranges of each item are different (see 
column 1 in Table 1). So, the coefficient expresses the change in the scores (measured in standard deviations) which may be observed on a given item for each category of education as compared to the lowest educational level. Noteworthy, temporal and space orientation, attention/calculation, reading, writing, and drawing scores improved as the level of education increased. Reading and writing, and drawing items displayed the largest coefficients, whereas there was no evidence that education exerted influence on naming and on the three step command tasks. Memory registration and repetition items were also influenced by education, but this association was weaker than the ones found for the items mentioned before. There was an unexpected inverse association between education and the delayed recall item.

\section{Discussion}

This study presents data on the contribution of categories of educational achievement to the scores of MMSE subscales and items with a special focus on lower educated communitydwelling elderly from a developing country. The items that were most influenced by the effect of education were attention/ calculation, reading, writing, and drawing. Education exerted a weaker influence on the repetition and on the memory registration items, whereas no effect was found on naming and on the three step command. These findings are in line with previous research wherein subjects with lower education made more mistakes on serial subtraction (attention/calculation), repetition, writing, and drawing tasks although the magnitude of group differences on each item performance was small. ${ }^{20}$ Another study, however, found that the repeating and naming items were also biased by the level of education. ${ }^{27}$ These results have been extensively commented by Jones and Gallo ${ }^{20}$ regarding the similarities and differences of their findings. One of the possible reasons for the differences from our own findings may be the clinical setting in Teresi's study, as cited by Jones and Gallo. ${ }^{20}$

Our study has included illiterate subjects whose scores were used as reference to the coefficients of the other educational categories. Education is not the only important factor for all of the tasks contained in the MMSE. Years of education or educational milestones do not account for all of the cognitive reserve and abilities in elderly subjects, although it has been also demonstrated that cognitive reserve associated to educational attainment mediates the symptom presentation and the clinical picture of the stages of Alzheimer's disease. ${ }^{28,29}$ An interesting study which was able to retrieve data from survivors of the Scottish Mental Survey in 1932 found no association between features of the sentence writing component of the MMSE and current cognitive ability, functional ability or depression score. However, raters were able to correctly estimate the IQ of the participants. ${ }^{16}$ Nonverbal and visual-constructive abilities are learnt and applied not only according to innate abilities but also as a response to the needs of the individual to adapt to the environment. Some of the skills which are necessary in order to cope with the everyday challenges in a city are continuously practiced without any formal education and cultural background certainly plays a role in the development of these skills. This may be one of the possible explanations why certain MMSE items simply do not show any difference dependent on the level of educational achievement. On the other hand, abilities like attention/calculation, reading, writing, and drawing are learnt early in school and are trained as years of formal education evolve, and for that matter education is a key factor for mastering these tasks. As mentioned before, cultural differences may also intervene to change some scores from right into wrong in the MMSE. In India, Tiwari et al. ${ }^{30}$ have compared the Hindi version of MMSE with the Hindi Mental State Examination (HMSE) so as to determine the applicability of this instrument in illiterate and literate subjects in that cultural background. They describe that the illiterate group scored highly on naming, memory registration, and repetition, whereas they have scored low on orientation to place, time, attention and calculation, reading, writing, and copying. Cross-cultural comparisons between developing countries which still have large proportions of illiterate elderly subjects could provide more data on the influence of culture to the development of cognitive skills.

Memory impairment is an axial symptom for the diagnosis of dementia. This feature is measured by the memory registration and by the delayed memory items of the MMSE. In our study, these two items showed a relatively weaker improvement in scores as education increased, even after controlling for age, sex, and ADL. Even though an unexplainable negative correlation occurred between the delayed memory scoring and education level, the correlation was rather weak. Also, despite the fact that this association achieved statistical significance, they were not at all comparable to the highly significant $\mathrm{p}$ values of the other items. So, it is conceivable to explain this finding as a type 1 error, i.e., a false positive finding due to chance.

Clinically, this might convey an important message that a low score on these two items may be a positive sign of impending impairment, regardless of the educational background. Indeed, Braekhus et al., ${ }^{14}$ in a quite different educational and cultural environment, came to the conclusion that two of the items pertaining to space orientation, as well as naming, reading, and memory registration actually performed poorly to detect dementia at a 23/24 cutoff. They also showed that a 12 -item version of the MMSE would still have a good discriminant power for detecting cognitive impairment and dementia. Our study shows that some of the same items commented in Braekhus et al. ${ }^{14}$ study (naming and memory registration) do not have a marked influence from years of education. It is conceivable to present the hypothesis that items which do not directly associate with educational levels could yield more reliable data related to suspicion of dementia in subjects with different levels of education. Also, as the three items which showed no relationship with education are the ones with the highest mean and the lowest variability in our study, it could be that an effect of education would show up in a sample including more cognitively impaired subjects. 
Recent studies in Brazilian community-dwelling elderly, both with lower income and low education levels, have confirmed the MMSE as a structure valid instrument ${ }^{19}$ and have also shown that it presents several limitations when screening populations with low educational and low socioeconomic levels. Scazufca et al. ${ }^{2}$ showed that many participants with no formal education did rate several MMSE items incorrectly, yielding lower sensitivity and specificity estimates of dementia than the ones found for higher educated subjects in a community based population. It is certainly difficult to rely solely on the MMSE scores as the only screening measure of possible dementia in such a population, and the use of activities of daily living scales together with MMSE is able to improve the ascertainment of a case. In our study, we also controlled association between education and MMSE for ADL, besides sex and age. The relation between education and the MMSE scores remained significant for some but not all the items. The different impact of education on each item may also lead to interpretations on clinical grounds. Based on this finding, it is conceivable to present the hypothesis that items that focus on memory performance in the MMSE remain important to screen for dementia in all educational levels, including illiterate subjects, regardless of the MMSE total score. These items are rather simple questions and do not seem to be much dependent on the cognitive reserve generated by formal education. On the other hand, items that make use of writing, reading and calculation skills are more prone to be influenced by education level.

This study has some limitations that should be acknowledged. We did not have sufficient information on the exact duration of education for each subject. This is mainly due to the fact that the subjects lacked documents to prove their educational attainment and gave rough estimations of the number of years they spent in school. Based on their answer, we were able to categorize them into the former levels of basic education in Brazil, 1-8 years, 9-12, and more than 12 years. Also, we did not have enough subjects at the highest level of education, a fact that may be explained by the economic and social characteristics of the region and of the town where the subjects live. ${ }^{23}$ The findings for this category need to be interpreted with caution due to the low accuracy generated by the small number of subjects.

To the best of our knowledge, this is the first study in Brazil to examine the impact of education on MMSE subscales and items. Education does not exert a homogeneous effect on items that sum up to 11 to the total MMSE score (naming, three step command, memory registration, and delayed memory). Also, as memory is a key factor to make a diagnosis of dementia, the results point that at least memory registration and delayed memory can be used to screen subjects not taking education into account for that matter.

\section{Acknowledgements}

To Luzinete N.O. Alvarenga for her editorial assistance. To Estevão de Paula, a bright student who participated in this research for several years before his premature death. 


\section{Disclosures}

\begin{tabular}{|c|c|c|c|c|c|c|c|}
\hline $\begin{array}{l}\text { Writing group } \\
\text { member }\end{array}$ & Employment & $\begin{array}{c}\text { Research } \\
\text { grant }^{1}\end{array}$ & $\begin{array}{c}\text { Other research grant } \\
\text { or medical continuous } \\
\text { education }^{2}\end{array}$ & $\begin{array}{l}\text { Speaker's } \\
\text { honoraria }\end{array}$ & $\begin{array}{c}\text { Ownership } \\
\text { interest }\end{array}$ & $\begin{array}{l}\text { Consultant } \\
\text { Advisory } \\
\text { board }\end{array}$ & Other $^{3}$ \\
\hline Jerson Laks & UFRJ & $\begin{array}{c}\text { CNPq } \\
\text { FAPERJ }^{\star \star \star}\end{array}$ & $\begin{array}{l}\text { Novartis } \\
\text { Janssen } \\
\text { Apsen } \\
\text { GSK } \\
\text { Wyeth } \\
\text { Lilly** }\end{array}$ & - & - & $\begin{array}{c}\text { Novartis } \\
\text { Janssen } \\
\text { GSK } \\
\text { Wyeth } \\
\text { Lilly** }\end{array}$ & - \\
\hline $\begin{array}{l}\text { Evandro Silva } \\
\text { Freire Coutinho }\end{array}$ & FIOCRUZ & $\begin{array}{c}\text { CNPq } \\
\text { FAPERJ*** }\end{array}$ & - & - & - & - & - \\
\hline $\begin{array}{l}\text { Washington } \\
\text { Junger }\end{array}$ & UERJ & - & - & - & - & - & - \\
\hline Heitor Silveira & UFRJ & $\mathrm{CNPq}^{* *}$ & - & - & - & - & - \\
\hline Raphael Mouta & UFRJ & - & - & - & - & - & - \\
\hline $\begin{array}{l}\text { Elienai Maria } \\
\text { Rubim Baptista }\end{array}$ & $\begin{array}{c}\text { General Health } \\
\text { System/Ministry of } \\
\text { Health }\end{array}$ & - & - & - & - & - & - \\
\hline $\begin{array}{l}\text { Ana Lucia } \\
\text { Barros Contino }\end{array}$ & $\begin{array}{c}\text { General Health } \\
\text { System/Ministry of } \\
\text { Health }\end{array}$ & - & - & - & - & - & - \\
\hline $\begin{array}{l}\text { Maria Lage } \\
\text { Barca }\end{array}$ & $\begin{array}{l}\text { Ullevaal University } \\
\text { Hospital University of } \\
\text { Oslo }\end{array}$ & - & - & - & - & - & - \\
\hline Geir Selbaek & $\begin{array}{c}\text { Innlandet Hospital } \\
\text { Trust }\end{array}$ & - & - & - & - & - & - \\
\hline Knut Engedal & $\begin{array}{l}\text { Ullevaal University } \\
\text { Hospital University of } \\
\text { Oslo }\end{array}$ & - & - & - & - & - & - \\
\hline $\begin{array}{l}\text { Eliasz } \\
\text { Engelhardt }\end{array}$ & UFRJ & Janssen ${ }^{\star \star}$ & - & - & - & - & - \\
\hline \multicolumn{8}{|c|}{$\begin{array}{l}\text { *Modest } \\
* * \text { Significant } \\
\text { *** Significant. Amounts given to the author's institution or to a colleague for research in which the author has participation, not directly to the } \\
\text { author. } \\
\text { Note: UFRJ = Universidade Federal do Rio de Janeiro; FIOCRUZ = Fundação Oswaldo Cruz; UERJ = Universidade Estadual do Rio de Janeiro; } \\
\text { CNPq = Conselho Nacional de Desenvolvimento Científico e Tecnológico; FAPERJ = Fundação de Amparo à Pesquisa do Estado do Rio de } \\
\text { Janeiro. } \\
\text { For more information, see Instructions for Authors. }\end{array}$} \\
\hline
\end{tabular}

References

1. Folstein MF, Folstein SE, McHugh PR. Mini-Mental State: a practical method for grading the cognitive state of patients for the clinician. J Psychiatr Res. 1975;12(3):189-98.

2. Scazufca M, Almeida OP, Vallada HP, Tasse WA, Menezes PR. Limitations of the Mini-Mental State Examination for screening dementia in a community with low socioeconomic status. Results from the São Paulo, Ageing \& Health Study. Eur Arch Psychiatry Clin Neurosc. 2009;259(1):8-15.

3. O'Bryant SE, Humphreys JD, Smith GE, Ivnik RJ, Graff-Radford NR, Petersen RC, Lucas JA. Detecting dementia with the Mini-Mental State Examination in highly educated individuals. Arch Neurol. 2008;65(7):963-7.

4. Crum RM, Anthony JC, Bassett SS, Folstein MF. Population-based norms for the Mini-Mental State Examination by age and educational level. JAMA. 1993;269(18)2386-91.

5. Rosselli D, Ardila A, Pradilla G, Morillo L, Bautista L, Rey O, Camacho M. El examen mental abreviado (Mini-Mental State Examination) como prueba de selección para el diagnóstico de demencia: estudio poblacional colombiano. Rev Neurol. 2000;30(5):428-32.

6. Keskinoglu P, Ucku R, Yener G, Yaka E, Kurt P, Tunca Z. Reliability and validity of revised Turkish version of Mini Mental State Examination (rMMSE-T) in community dwelling educated and uneducated elderly. Int J Geriatr Psychiatry. 2009;24(11):1242-50.
7. Bertolucci PH, Brucki SM, Campacci SR, Juliano Y. The Mini-Mental State Examination in a general population: impact of educational status. Arq Neuropsiquiatr. 1994;52(1):1-7.

8. Almeida OP. Mini-Mental State Examination and the diagnosis of dementia in Brazil. Arq Neuropsiquiatr. 1998;56(3B):605-12.

9. Caramelli P, Herrera E Jr, Nitrini R. The Mini-Mental Examination and the diagnosis of dementia in illiterate elderly. Arq Neuropsiquiatr. 1999;57(Suppl 1):S7.

10. Anderson TM, Sachdev PS, Brodaty H, Trollor JN, Andrews G. Effects of sociodemographic and health variables on Mini-Mental State Exam scores in older Australians. Am J Geriatr Psychiatry. 2007;15(6):467-76.

11. Laks J, Baptista EM, Contino AL, de Paula EO, Engelhardt E. Mini-Mental State Examination norms in a community-dwelling sample of elderly with low schooling in Brazil. Cad Saude Publica. 2007;23(2):315-9.

12. Cullen B, Fahy S, Cunningham CJ, Coen RF, Bruce I, Greene E, Coakley D, Walsh JB, Lawlor BA. Screening for dementia in an Irish community sample using MMSE: a comparison of norm-adjusted versus fixed cutpoints. Int J Geriatr Psychiatry. 2005;20(4):371-6.

13. Castro-Costa E, Fuzikawa C, Uchoa E, Firmo JO, Lima-Costa MF. Norms for the Mini-Mental Examination. Adjustment of the cutoff point in population-based studies (evidences from the Bambuí health aging study). Arq Neuropsiquiatr. 2008;66(3A):524-8. 
14. Braekhus A, Laake K, Engedal K. The Mini-Mental State Examination: identifying the most efficient variables for detecting cognitive impairment in the elderly. J Am Geriatr Soc. 1992;40(11):1139-45.

15. Diniz BS, Yassuda MS, Nunes PV, Radanovic M, Forlenza OV. Mini-Mental State Examination performance in mild cognitive impairment subtypes. Int Psychogeriatrics. 2007;19(4):647-56.

16. Shenkin SD, Starr JM, Dunn JM, Carter S, Deary IJ. Is there information contained within the sentence-writing component of the Mini Mental State Examination? A retrospective study of community dwelling older people. Int J Geriatr Psychiatry. 2008;23(12):1283-9.

17. Brugnolo A, Nobili F, Barbieri MP, Dessi B, Ferro A, Girtler N, Palummeri E, Partinico D, Raiteri U, Regesta G, Servetto G, Tanganelli P, Uva V, Mazzei D, Donadio S, De Carli F, Colazzo G, Serrati C, Rodriguez G. The factorial structure of the mini mental state xamination (MMSE) in Alzheimer's disease. Arch Gerontol Geriatr. 2009;49(1):180-5.

18. Petersen RC, Stevens JC, Ganguli M, Tangalos EG, Cummings JL, DeKosky ST. Practice parameter: early detection of dementia. Mild cognitive impairment (an evidence-based review). Report of the Quality Standards Subcommittee of the American Academy of Neurology. Neurology. 2001;56(9):1133-42.

19. Castro-Costa E, Fuzikawa C, Ferri C, Uchoa E, Firmo J, Lima-Costa MF, Dewey ME, Stewart R.. Dimensions underlying the Mini-Mental State Examination in a sample with low education levels The Bambui Health and Aging Study (BHAS). Am J Geriatr Psychiatry. 2009;17(10):863-72.

20. Jones RN, Gallo JJ. Education and sex differences in the Mini-Mental State Examination: effects of differential item functioning. J Gerontol B Psychol Sci Soc Sci. 2002;57(6):548-58.

21. Jones RN, Gallo JJ. Education bias in the Mini-Mental State Examination. Int Psychogeriatrics. 2001;13(3):299-310.

22. Pfeffer RI, Kurosaki T, Harrah CH. Measurement of functional activities in older adults in the community. J Gerontol. 1982;37(3):323-9.

23. Instituto Brasileiro de Geografia e Estatística-IBGE. (2000). Censo Brasil. [citado 20 maio 2009]. Disponível em: http://www.ibge.gov.br/censo 2000.

24. Laks J, Batista EM, Guilherme ER, Contino AL, Faria ME, Rodrigues CS, de Paula E, Engelhardt E. Prevalence of cognitive and functional impairment in community-dwelling elderly: importance of evaluating activities of daily living. Arq Neuropsiquiatr. 2005;63(2A):207-12.

25. Brucki SM, Nitrini R, Caramelli P, Bertolucci PH, Okamoto IH. Sugestôes para o uso do mini-exame do estado mental no Brasil. Arq Neuropsiquiatr. 2003;61(3B):777-81.

26. $\mathrm{R}$ Development Core Team. R: A language and environment for statistical computing. R Foundation for Statistical Computing, Vienna, Austria. 2009. [cited 2009 maio 20]. Available from: http://www.R-project.org.

27. Teresi J, Golden R, Cross P, Gurland B, Kleinman M, and Wilder D. Item bias in cognitive screening measures: Comparisons of elderly White, Afro-American, Hispanic and high and low education subgroups. J Clin Epidemiol. 1995;48(4):473-83.

28. Stern Y. Cognitive reserve and Alzheimer's disease. Alzheimer Dis Assoc Disord. 2006;20(Suppl 2):S69-S74.

29. Scarmeas N, Albert SM, Manly JJ, Stern Y. Education and rates of cognitive decline in incident Alzheimer's disease. J Neurol Neurosurg Psychiatry. 2006;77(3):308-16.

30. Tiwari SC, Tripathi RK, Kumar A. Applicability of the Mini-Mental State Examination (MMSE) and the Hindi Mental State Examination (HMSE) to the urban elderly in India: a pilot study. Int Psychogeriatrics. 2009;21(1):123-8 